Article

\title{
Inorganic Macro- and Micronutrients in "Superberries" Black Chokeberries (Aronia melanocarpa) and Related Teas
}

\author{
Iva Juranović Cindrić ${ }^{1}$, Michaela Zeiner ${ }^{2, *}$, Darija Mihajlov-Konanov ${ }^{1}$ and Gerhard Stingeder ${ }^{2}$ \\ 1 Division of Analytical Chemistry, Department of Chemistry, Faculty of Science, University of Zagreb, \\ Horvatovac 102a, 10000 Zagreb, Croatia; ijuranovic@chem.pmf.hr (I.J.C.); darija1512@gmail.com (D.M.-K.) \\ 2 Department of Chemistry, University of Natural Resources and Life Sciences, Muthgasse 18, Vienna 1190, \\ Austria; gerhard.stingeder@boku.ac.at \\ * Correspondence: michaela.zeiner@boku.ac.at; Tel.: +43-1-47654-77194
}

Academic Editor: Susanne Charlesworth

Received: 11 April 2017; Accepted: 16 May 2017; Published: 18 May 2017

\begin{abstract}
Black chokeberries (Aronia melanocarpa) are considered to be functional food containing high amounts of anthocyanins, phenols, antioxidants, vitamins and minerals. Whereas organic compounds are well studied, there is little research on the mineral composition of the chokeberries. Thus, the presented study is focused on the determination of $\mathrm{Al}, \mathrm{As}, \mathrm{Ba}, \mathrm{Ca}, \mathrm{Cd}, \mathrm{Co}, \mathrm{Cr}, \mathrm{Cu}, \mathrm{Fe}, \mathrm{K}$, $\mathrm{Li}, \mathrm{Mg}, \mathrm{Mn}, \mathrm{Mo}, \mathrm{Na}, \mathrm{Ni}, \mathrm{Pb}, \mathrm{Se}, \mathrm{Sr}$ and $\mathrm{Zn}$ in black chokeberry fruits and infusions to study the metals' extractability. The nutrients $\mathrm{Ca}, \mathrm{K}$ and $\mathrm{Mg}$ are present in the fruits (dried matter) at $\mathrm{g} / \mathrm{kg}$ level, whereas the other elements are present from $\mu \mathrm{g} / \mathrm{kg}$ up to $\mathrm{mg} / \mathrm{kg}$ level. The extraction yields of the metals from the infusion range from $4(\mathrm{Al}, \mathrm{Mn})$ up to $44 \%(\mathrm{Na})$. The toxic elements present do not pose any health risk when berries or infusions are consumed. Concluding, Aronia berries, as well as infusions derived from them, are a good dietary source of essential metals in addition to the organic compounds also contained.
\end{abstract}

Keywords: Aronia melanocarpa; berries; infusions; mineral content; extraction yield

\section{Introduction}

Aronia melanocarpa (black chokeberry), belonging to Rosaceae family, originally coming from North America is now widely used also in Europe as a "superberry" due to its high content of nutrients being especially beneficial for health and well-being. Not only do scientific papers describe the beneficial properties of this berry [1], but this fruit is also popularized in non-scientific journals [2]. The Aronia plant can reach a height of 2 to $3 \mathrm{~m}$. The fruits, dark because of a high amount of anthocyanins, have a diameter of 6-13 $\mathrm{mm}$ and weigh between 0.5 and $2 \mathrm{~g}$. The ripe berries are usually harvested in August and September. Aronia is nowadays commonly used in different European countries as berries themselves or processed as syrup, juice, jellies and tea [3]. The fruits are rich in polyphenols and have thus been intensively investigated for its medicinal potentials. Besides the antioxidative activity [4], Aronia contains components such as isoquercetin, kaempferol, ferulic acid, caffeic acid, ellagic acid, myricetin and hydroxybenzoic acids, which all have been found to exhibit anti-influenza activities [5]. Cytotoxic effects against cervix carcinoma, melanoma, colon, and chronic myelogenous leukemia cell lines have been correlated with the phenolic constituents [6] while anthocyanins extracted from chokeberry juices provide positive effects against colon cancer $[7,8]$. Due to these biological activities chokeberries are considered as a functional food. Compared with other berries, Aronia berries contain a lot of cyanidin glycosides, only beaten by elderberry [9] and bilberry [10]. 
While a large number of scientific publications focus on the organic compounds in the berries responsible for different medicinal activities, only few reports on the inorganic pattern of these berries, either on toxic or on essential elements, were found $[3,11]$. Berries in general are a rich source of macroand microelements [12]. Already in the 1940s, Chandler stated that berries have unsurpassed ability in accumulating essential elements among fruiting plants [13]. Thus, not only is the metal content of the berries themselves is of interest, but also their extraction yield too, since berries are widely consumed as infusions or juices.

Furthermore, it has been proven that certain elements enhanced the production of the flavonoids leading to the beneficial effects of berries $[14,15]$. The dietary intake of chokeberries can also be promoted due to the metal ion binding capacity of its fibers. Whilst $\mathrm{Mg}$ is desorbed under digestive conditions, harmful elements, such as $\mathrm{Cd}, \mathrm{Pb}, \mathrm{Cu}, \mathrm{Zn}$ are absorbed [16,17].

Thus, the main objective of the present paper is the determination of harmful and beneficial elements in berries and infusions prepared from them in order to get a complete picture of the berries' composition.

\section{Materials and Methods}

\subsection{Chemicals and Glassware}

Nitric acid (suprapure) and inductively coupled plasma (ICP) Multi-element Standard IV were purchased from Merck (Darmstadt, Germany). The standard reference material of strawberry leaves (LGC7162) used was obtained from LGC Standards (Middlesex, London, UK).

All plastic (PE) and glassware was cleaned with diluted nitric acid prior to use. Ultrapure water was produced by an in-house water preparation system.

\subsection{Samples}

Aronia berries $(n=11)$ were purchased from local markets for organically grown food in Croatia (2011), dried for $24 \mathrm{~h}$ at $105^{\circ} \mathrm{C}$, homogenized in a metal free mortar and stored in a dry and dark room at ambient temperature prior to digestion.

\subsection{Sample Preparation}

All plant samples were digested using a closed microwave assisted system, as it is state of the art for such samples [18].

For the sample preparation, a MWS-2 Microwave System Speedwave from Berghof Laborprodukte $\mathrm{GmbH}$ (Eningen, Germany) was used. Each sample (berries and CRM) was digested in duplicate, whereby about $0.3-0.5 \mathrm{~g}$ (weighed to the nearest $0.1 \mathrm{mg}$ ) was put into a Teflon reaction vessel and $5 \mathrm{~mL}$ $\mathrm{HNO}_{3}(50: 50 \mathrm{v} / \mathrm{v})$ were added. The digestion procedure was carried out according to the following program consisting of three steps of $15 \mathrm{~min}$ each: $110^{\circ} \mathrm{C}-170{ }^{\circ} \mathrm{C}-140^{\circ} \mathrm{C}$. Blank solutions were prepared in the same way.

The clear solutions were obtained and then brought to final $10.0 \mathrm{~mL}$ with ultrapure water.

The infusions were prepared by addition of $98 \mathrm{~mL}$ boiling ultrapure water to $2.0-2.4 \mathrm{~g}$ (weighed to the nearest $0.1 \mathrm{mg}$ ) of dried berries. Different decoction times were applied, namely 1, 5, 10, 20 and $30 \mathrm{~min}$. The final infusions were filtered using Whatman No 541 filter paper (Merck; Darmstadt, Germany) in order to have clear solutions for the measurements by inductively coupled plasma-atomic emission spectrometry (ICP-AES).

\subsection{ICP-AES Measurements}

The elemental concentrations in the digests and the infusions were measured in triplicate by a Prodigy High Dispersive ICP-AES spectrometer from Teledyne Leeman (Hudson, NH, USA) working in a simultaneous mode. The optimal instrumental conditions are listed in Table 1 and the emission lines used were: Al 308.215 nm, Ba 455.403 nm, Ca 396.847 nm, Cd 214.441 nm, Co 228.615 nm, 
Cr 206.149 nm, Cu 224.700 nm, Fe 238.204 nm, K 766.491 nm, Mg 280.271 nm, Mn 257.610 nm, Na 589.592 nm, Ni 231.604 nm, Pb 220.353 nm, Sr 407.771 nm, and Zn 213.856 nm.

Table 1. ICP-AES operating conditions.

\begin{tabular}{cc}
\hline Instrument & Prodigy High Dispersive ICP \\
\hline Spectrometer & High resolution Echelle polychromator Large format programmable array detector (L-PAD) \\
RF-Generator & $40 \mathrm{MHz}$ "free-running" \\
Output power & $1.1 \mathrm{~kW}$ \\
Argon flow & Coolant: $18 \mathrm{~L} / \mathrm{min}$, Auxiliary: $0.8 \mathrm{~L} / \mathrm{min}, \mathrm{Nebulizer:} 1 \mathrm{~L} / \mathrm{min}$ \\
Peristaltic pump & $1.0 \mathrm{~mL} \mathrm{~min}$ "- \\
Nebulizer & Pneumatic (glass concentric) \\
Spray chamber & Glass cyclonic \\
Plasma viewing & Axial \\
Replicates for each analysis run & 3 \\
Sample uptake delay & $30 \mathrm{~s}$ \\
\hline
\end{tabular}

The quantification was done by external calibration using multi-element standard solutions in the concentration range from $0.05 \mathrm{mg} / \mathrm{L}$ to the expected maximum concentration ranging from 5 to $20 \mathrm{mg} / \mathrm{L}$ of the elements of interest. The standard solutions were prepared by dilution of a multi-element standard stock solution $(1000 \mathrm{mg} / \mathrm{L})$ with $1 \%$ w/w $\mathrm{HNO}_{3}$. Blank solutions were prepared in the same medium.

\subsection{Inductively Coupled Plasma-Mass Spectrometry (ICP-MS) Measurements}

Additionally, the elements were quantified with high-resolution inductively coupled plasma-sector field mass spectrometry (ICP-SFMS) (Element 2 ICP-SFMS from Thermo Fisher; Bremen, Germany). The instrument was equipped with a self-aspirating PFA microflow nebulizer (ESI: Elemental Scientific Inc., Omaha, NE, USA; flow of $100 \mathrm{~mL} / \mathrm{min}$ ), a Peltier cooled $\left(\mathrm{PC}^{3}\right)$ cyclonic quartz chamber (ESI: Elemental Scientific Inc., Omaha, NE, USA; operated at $4{ }^{\circ} \mathrm{C}$ ), a quartz injector pipe and torch, aluminum sampler and skimmer cone (all from Thermo Fisher). The instrumental conditions applied were: radio frrequency $(\mathrm{RF})$ power- $1300 \mathrm{~W}$ and plasma gas flow- $16 \mathrm{~L} / \mathrm{min}$, sample gas- $1.06 \mathrm{~L} / \mathrm{min}$ and auxiliary gas flows $-0.86 \mathrm{~L} / \mathrm{min}$.

The isotopes were analyzed at different resolutions, low resolution $\left({ }^{7} \mathrm{Li}^{+},{ }^{82} \mathrm{Se}^{+},{ }^{88} \mathrm{Sr}^{+},{ }^{111} \mathrm{Cd}^{+}\right.$, $\left.{ }^{208} \mathrm{~Pb}^{+}\right)$, medium resolution $\left({ }^{52} \mathrm{Cr}^{+},{ }^{55} \mathrm{Mn}^{+},{ }^{56} \mathrm{Fe}^{+},{ }^{59} \mathrm{Co}^{+},{ }^{60} \mathrm{Ni}^{+},{ }^{65} \mathrm{Cu}^{+},{ }^{66} \mathrm{Zn}^{+},{ }^{98} \mathrm{Mo}^{+}\right)$and high resolution $\left({ }^{75} \mathrm{As}^{+}\right)$, with the nominal mass resolutions of 350, 4500 and 10,000, respectively. At all resolution levels Indium $(1.1 \mu \mathrm{g} / \mathrm{L})$ was used as internal standard, measured as ${ }^{115} \mathrm{In}^{+}$.

\subsection{Optimisation and Characterisation of the Analytical Method}

The trueness of the method for digests was determined by analyzing strawberry leaves reference material. For the infusions, spiking experiments were performed to determine the recovery: aqueous multi-element standard solutions were added to a set of infusions in triplicate at three concentration levels $(1.0,3.0$ and $5.0 \mathrm{mg} / \mathrm{L}$ ) according to the expected concentration range.

The overall repeatability of the instruments was determined by analyzing three samples after calibration on two different days. The precision as relative standard deviation (RSD) was evaluated by measuring certain samples five times.

The limits of detection (LOD) were calculated according to Boumans [19] using $3 \sigma$.

\section{Results and Discussion}

\subsection{Analytical Methods}

The results from the blank solutions (digest solution, infusion blank) are subtracted from the sample values, so all the data given in the following are blank corrected. 
The trueness, describing how close the test result is to the true result, is expressed by recoveries determined by analyzing the standard reference material of strawberry leaves (LGC7162) and ranged from 85 up to $109 \%$ for both analytical methods (Table 2). The recoveries were calculated according to the following formula:

$$
\text { recovery }_{x}=\frac{\text { content }_{x, \text { found }}[\mathrm{mg} / \mathrm{kg}]}{\text { content }_{x, \text { certified }}[\mathrm{mg} / \mathrm{kg}]} \times 100
$$

The spiking experiments for the infusions resulted in recovery rates from 92 to $106 \%$ for ICP-AES (Table 3), whereby the recoveries were calculated according to the following formula:

$$
\text { recovery }_{x}=\frac{\text { concentration }_{x, \text { spiked solution }}[\mu \mathrm{g} / \mathrm{L}]-\text { concentration }_{x, \text { unspiked solution }[\mu \mathrm{g} / \mathrm{L}]}}{\text { concentration }_{x} \text {, added }[\mu \mathrm{g} / \mathrm{L}]} \times 100
$$

High particulate matter in the infusions even after an additional centrifugation step caused plugging of the ICP-MS tubes, so the infusions could not be measured by ICP-MS. Thus, there are no results for $\mathrm{As}, \mathrm{Li}$, Mo and Se.

The LODs in the digested berries were below $1 \mathrm{mg} / \mathrm{kg}$ for ICP-AES and up to $20 \mu \mathrm{g} / \mathrm{kg}$ for ICP-MS for the elements studied (see Table 4). The LODs determined for the metals in infusions are presented in Table 5.

Regarding the calibration curves, the coefficients of determination $\left(R^{2}\right)$ were higher than 0.9990 .

The precision determined by repeated measurements led to RSD values in the range from 0.02 up to $1.8 \%$, while the day-to-day repeatability for all metals was below $<1.9 \%$.

All these obtained analytical parameters are in the range for the determination of micro- and macro-elements in biological samples. 
Table 2. Recoveries and certified data for analytes in CRM strawberry leaves (LGC7162).

\begin{tabular}{|c|c|c|c|c|c|c|c|c|c|c|c|c|c|c|c|c|c|c|c|c|}
\hline Content [mg/kg] & $\mathrm{Al}$ * & As & Ba & $\mathrm{Ca}$ & $\mathrm{Cd}$ & Co & $\mathrm{Cr}$ & $\mathrm{Cu}$ * & $\mathrm{Fe}$ & $\mathbf{K}$ & $\mathbf{L i}^{*}$ & $\mathrm{Mg}$ & Mn & Mo & $\mathrm{Na} *$ & $\mathbf{N i}$ & $\mathrm{Pb}$ & $\mathrm{Se}^{*}$ & $\mathrm{Sr}$ & $\mathrm{Zn}$ \\
\hline found & 1036 & 0.278 & 112 & 15,181 & 0.186 & 0.459 & 1.87 & 8.7 & 791 & 20,313 & 0.623 & 3829 & 162 & 0.300 & 218 & 2.30 & 1.78 & 0.347 & 63.8 & 21.5 \\
\hline certified value & & 0.28 & 107 & 15,300 & 0.17 & 0.47 & 2.15 & & 818 & 19,600 & & 3770 & 171 & 0.32 & & 2.6 & 1.8 & & 64 & 24 \\
\hline confidence interval & 1000 & 0.07 & 10 & 700 & 0.04 & 0.11 & 0.34 & 10 & 48 & 1000 & 0.7 & 170 & 10 & 0.08 & 210 & 0.7 & 0.4 & 0.04 & 6 & 5 \\
\hline method & AES & MS & AES & AES & MS & MS & MS & MS & AES & AES & MS & AES & AES & MS & AES & MS & MS & MS & MS & AES \\
\hline recovery in \% & 104 & 99 & 105 & 99 & 109 & 98 & 87 & 87 & 97 & 104 & 89 & 102 & 95 & 94 & 104 & 85 & 99 & 87 & 100 & 90 \\
\hline
\end{tabular}

* only indicative value for this element.

Table 3. Recoveries for analytes in infusions.

\begin{tabular}{cccccccccccccccccc}
\hline Concentration $[\mathrm{mg} / \mathbf{L}]$ & $\mathbf{A l}$ & $\mathbf{B a}$ & $\mathbf{C a}$ & $\mathbf{C d}$ & $\mathbf{C o}$ & $\mathbf{C r}$ & $\mathbf{C u}$ & $\mathbf{F e}$ & $\mathbf{K}$ & $\mathbf{M g}$ & $\mathbf{M n}$ & $\mathbf{N a}$ & $\mathbf{N i}$ & $\mathbf{P b}$ & $\mathbf{S r}$ & $\mathbf{Z n}$ \\
\cline { 1 - 1 } & 1 & 1 & 5 & 1 & 1 & 1 & 1 & 3 & 5 & 3 & 1 & 5 & 1 & 1 & 1 & 1 \\
spiked & 1.02 & 1.03 & 4.87 & 1.06 & 1.04 & 1.02 & 0.976 & 2.84 & 5.12 & 3.08 & 0.957 & 4.73 & 0.981 & 1.02 & 0.924 & 0.976 \\
found & 102 & 103 & 97 & 106 & 104 & 102 & 98 & 95 & 102 & 103 & 96 & 95 & 98 & 102 & 92 & 98 \\
recovery in $\%$ & & & & & & & &
\end{tabular}

Table 4. Elemental composition of Aronia berries in $\mathrm{mg} / \mathrm{kg}$ dried matter (mean values and standard deviation, SD; $n=11$ ).

\begin{tabular}{|c|c|c|c|c|c|c|c|c|c|c|c|c|c|c|c|c|c|c|c|c|c|}
\hline Sample/Method & Determined Value & $\mathrm{Al}$ & As & Ва & $\mathrm{Ca}$ & $\mathrm{Cd}$ & Co & $\mathrm{Cr}$ & $\mathrm{Cu}$ & $\mathrm{Fe}$ & $\mathrm{K}$ & $\mathbf{L i}$ & $\mathrm{Mg}$ & Mn & Mo & $\mathrm{Na}$ & $\mathrm{Ni}$ & $\mathrm{Pb}$ & Se & $\mathrm{Sr}$ & $\mathrm{Zn}$ \\
\hline Aronia berries & $\mathrm{LOD}[\mathrm{mg} / \mathrm{kg}]$ & 0.91 & 0.020 & 0.86 & 0.12 & 0.0005 & 0.0037 & 0.0068 & 0.0072 & 0.05 & 0.27 & 0.0085 & 0.21 & 0.32 & 0.011 & 0.059 & 0.0063 & 0.013 & 0.0047 & 0.06 & 0.35 \\
\hline analytical method & & AES & MS & AES & AES & MS & MS & MS & MS & AES & AES & MS & AES & AES & MS & AES & MS & MS & MS & MS & AES \\
\hline Aronia berries & $\begin{array}{l}\text { content }[\mathrm{mg} / \mathrm{kg}] \\
\mathrm{SD}[\mathrm{mg} / \mathrm{kg}]\end{array}$ & $\begin{array}{l}158 \\
72\end{array}$ & a & a & $\begin{array}{l}1212 \\
310\end{array}$ & $\begin{array}{l}0.055 \\
0.027\end{array}$ & $\begin{array}{l}0.019 \\
0.001\end{array}$ & $\begin{array}{l}0.029 \\
0.018\end{array}$ & $\begin{array}{l}1.58 \\
0.07\end{array}$ & $\begin{array}{l}1.32 \\
0.05\end{array}$ & $\begin{array}{l}6790 \\
308\end{array}$ & $\begin{array}{l}0.012 \\
0.001\end{array}$ & $\begin{array}{l}669 \\
89\end{array}$ & $\begin{array}{l}0.829 \\
0.123\end{array}$ & $\begin{array}{l}0.039 \\
0.016\end{array}$ & $\begin{array}{l}4.27 \\
1.22\end{array}$ & $\begin{array}{l}0.38 \\
0.02\end{array}$ & $\begin{array}{l}0.041 \\
0.021\end{array}$ & a & $\begin{array}{l}1.66 \\
0.40\end{array}$ & $\begin{array}{l}0.55 \\
0.13\end{array}$ \\
\hline Aronia berries [11] & content in fresh fruits $[\mathrm{mg} / \mathrm{kg}]$ & & & & 272 & & & & & & 2903 & & 155 & & & & & & & & \\
\hline Aronia berries [20] reported in [3] & content in fresh fruits $[\mathrm{mg} / \mathrm{kg}]$ & & & & 322 & & & & & 9.3 & 2180 & & 162 & & & 26 & & & & & 1.47 \\
\hline $\begin{array}{l}\text { Aronia berries [21] } \\
\text { (fresh fruits) }\end{array}$ & $\begin{array}{c}\text { content }[\mathrm{mg} / \mathrm{kg} \text { unpolluted area }(2003 / 04) \\
\text { content }[\mathrm{mg} / \mathrm{kg}] \text { polluted area }(2003 / 04)\end{array}$ & & & & & $\begin{array}{l}0.047 / 0 \\
0.047 / 0\end{array}$ & & & & & & & & & & & & $\begin{array}{l}0.012 / \\
0.043 /\end{array}$ & & & \\
\hline Hawthorn berries [22] & content $[\mathrm{mg} / \mathrm{kg}]$ & 917 & 0.012 & 4.17 & 3722 & 0.045 & 0.058 & 1.31 & 0.55 & 2.4 & 4223 & 0.51 & 987 & 1.88 & 0.097 & 6.34 & 0.067 & 0.027 & & 0.41 & 1.12 \\
\hline
\end{tabular}


Table 5. Elemental composition of infusions made from Aronia berries after 10 min decoction time (mean values and standard deviation, SD; $n=4$; infusions based on $2 \mathrm{~g}$ dried berries $+98 \mathrm{~mL}$ water).

\begin{tabular}{|c|c|c|c|c|c|c|c|c|c|c|c|c|c|c|c|c|c|}
\hline Sample/Method & Determined Value & Al & Ba & $\mathrm{Ca}$ & Cd & Co & $\mathrm{Cr}$ & $\mathrm{Cu}$ & $\mathrm{Fe}$ & K & $\mathrm{Mg}$ & Mn & $\mathrm{Na}$ & $\mathrm{Ni}$ & $\mathrm{Pb}$ & $\mathrm{Sr}$ & $\mathrm{Zn}$ \\
\hline infusions from Aronia berries & $\mathrm{LOD}[\mu \mathrm{g} / \mathrm{L}]$ & 0.58 & 0.09 & 2.1 & 0.41 & 0.57 & 0.77 & 0.40 & 0.21 & 0.05 & 2.8 & 0.08 & 0.09 & 1.0 & 5.1 & 0.07 & 0.81 \\
\hline \multirow{4}{*}{$\begin{array}{l}\text { analytical method } \\
\text { infusions from Aronia berries }\end{array}$} & $\mathrm{a}$ & AES & AES & AES & AES & AES & AES & AES & AES & AES & AES & AES & AES & AES & AES & AES & AES \\
\hline & Concentration $[\mu \mathrm{g} / \mathrm{L}]$ & 160 & 0.10 & 3235 & b & $\mathrm{b}$ & 3.2 & 3.3 & 0.31 & 21,821 & 1485 & 0.40 & 8.7 & 2.3 & $\mathrm{~b}$ & $\mathrm{~b}$ & 2.2 \\
\hline & $\mathrm{SD}[\mu \mathrm{g} / \mathrm{L}]$ & 14 & 0.04 & 89 & & & 0.4 & 0.03 & 0.02 & 264 & 72 & 0.02 & 0.3 & 0.1 & & & 0.1 \\
\hline & extraction yield in \% & 4.3 & n.c. & 7.6 & & & 25 & 27 & 9.5 & 11 & 7.2 & 4.0 & 44 & 20 & & & 23 \\
\hline $\begin{array}{l}\text { extracts from Aronia berries } 50 \mathrm{~g} \\
\text { berries in } 200 \mathrm{~mL} \text { solution [23] }\end{array}$ & concentration $[\mu \mathrm{g} / \mathrm{L}]$ & & & 29,530 & & & & & 620 & & 37,490 & & & & & & 2750 \\
\hline
\end{tabular}

${ }^{a}$ due to high organic and particulate matter (even after centrifugation) measurement of the infusions with ICP-MS was not possible; ${ }^{b}<$ LOD (limit of detection) n.c. not calculated. 


\subsection{Elemental Analysis of Berries}

Elemental composition of Aronia berries is listed in Table 4 as mean values along with the respective standard deviation of $n=11$. Arsenic, Ba and Se could not be detected in any samples. Furthermore, literature data $[11,20,21]$ for minerals in Aronia berries are presented in Table 4 . All three publications are focused only on few elements and in all cases the contents are determined in fresh fruits. Due to differences in water content in berries, such data can be used only for rough comparison. It can be clearly seen that the obtained results here are higher, since they are calculated for dried fruits, but in general the order of magnitude is in the same range. Ognik and colleagues investigated Aronia berries harvested in two different years as well as from different places, i.e., an unpolluted and polluted site [21]. Whereby no influence of pollution was observed for $\mathrm{Cd}, \mathrm{Pb}$ was found with four times higher concentration in the berries grown on polluted soil. Considering water content of $80 \%$, the results for lead by the Polish working group and those from the presented study are in good agreement. Comparing Aronia berries with the fruits from Crataegus monogyna [22], also a plant of the Rosaceae family, it can be seen that the majority of elements are present in lower amounts. $\mathrm{Cd}, \mathrm{Fe}, \mathrm{Mg}$, $\mathrm{Na}$, and $\mathrm{Pb}$ are in the same concentration range. The content of $\mathrm{Cu}, \mathrm{Ni}$, and $\mathrm{Sr}$ is even higher in Aronia berries. Since soil composition, ripeness state, climate and environmental conditions and genetic background influence the accumulation of elements, these obtained differences are to be expected [24].

In Table 6 the Recommended Dietary Allowances (RDA) are given for selected essential elements [25]. A daily intake of $10 \mathrm{~g}$ dried berries would cover only $1.2 \% ; 0.2 \% ; 0.8 \% ; 0.2 \% ; 1.7 \% ; 4 \%$; $0.3 \%$ and $0.05 \%$ of the daily needs of $\mathrm{Ca}, \mathrm{Cr}, \mathrm{Cu}, \mathrm{Fe}, \mathrm{Mg}, \mathrm{Mn}, \mathrm{Mo}$, and $\mathrm{Zn}$, respectively. From these values the conclusion can be drawn that Aronia berries can only contribute to a small but appreciable amount of the dietary metal uptake. There is also no health risk posed by toxic elements in the analyzed samples, but for the general conclusion more samples from a different sampling location have to be measured. The Joint FAO/WHO Expert Committee on Food Additives (JECFA) proposes Provisional Tolerable Weekly Intake values (PTWI) for harmful elements in food: for $\mathrm{Cd}, \mathrm{Cr}, \mathrm{Cu}$ and $\mathrm{Pb}$ listed in Table 7 [26,27]. Considering a consumption of $100 \mathrm{~g}$ dried Aronia berries in per week and a body weight of $80 \mathrm{~kg}$, the total intake in $\mu \mathrm{g}$ as well as in $\mu \mathrm{g} / \mathrm{kg}$ body weight (BW) was calculated and the data are presented in Table 7. Only for $\mathrm{Cu}$ is the amount close to the given PTWI value (57\%), whilst for the other toxic elements no negative health effect is to be expected $(1.0 \%, 0.15 \%$ and $2.0 \%$ for $\mathrm{Cd}, \mathrm{Cr}$ and $\mathrm{Pb}$, resp.).

Table 6. Recommended Dietary Allowances (RDA) for adults for determined essential elements [25].

\begin{tabular}{cccc}
\hline Element & RDA [mg/day] & Element & RDA [mg/day] \\
\hline $\mathrm{Ca}$ & 1000 & $\mathrm{Mg}$ & 400 \\
$\mathrm{Cr}$ & 0.120 & $\mathrm{Mn}$ & 2 \\
$\mathrm{Cu}$ & 2 & & \\
$\mathrm{Fe}$ & 8 & $\mathrm{Mo}$ & 0.120 \\
& & $\mathrm{Zn}$ & 11 \\
\hline
\end{tabular}

Table 7. PTWI for determined harmful elements along with calculated intake by consumption of $100 \mathrm{~g}$ dried berries.

\begin{tabular}{|c|c|c|c|}
\hline Element & PTWI $[26,27][\mu \mathrm{g} / \mathrm{kg}$ BW] & $\begin{array}{l}\text { Mass in } 100 \mathrm{~g} \text { Dried } \\
\text { Berries }[\mu \mathrm{g}]\end{array}$ & $\begin{array}{c}\text { Weekly Intake by Consumption of } \\
100 \mathrm{~g} \text { Dried Berries }\end{array}$ \\
\hline $\mathrm{Cd}$ & 7.0 & 5.5 & 0.069 \\
\hline $\mathrm{Cr}$ & 23.3 & 2.9 & 0.036 \\
\hline $\mathrm{Cu}$ & 3.5 & 158 & 2.0 \\
\hline $\mathrm{Pb}$ & 25 & 4.1 & 0.051 \\
\hline
\end{tabular}




\subsection{Elemental Analysis of Infusions}

Different decoctions times were applied in order to find the optimum one. The resulting metal concentrations from macro- and microelements depending on the extraction period ranging from 5-30 min are presented in Figure 1. For all elements more than $95 \%$ of the maximum extracted concentration is reached after $10 \mathrm{~min}$, thus this period can be recommended for preparing tea from Aronia berries. Thus, the determined elemental concentrations for $10 \mathrm{~min}$ extraction time are used for further discussion and presented in Table 5 along with the standard deviation $(n=4)$. Since the remaining particulate matter in the infusions led to tube plugging of ICP-MS, not all analytes could be analyzed in the infusions, i.e., As, $\mathrm{Li}, \mathrm{Mo}$ and Se are not addressed. Aqueous extraction of Aronia berries was also described by Pliszka and co-workers [23]. They mixed $200 \mathrm{~mL}$ of water at room temperature with $50 \mathrm{~g}$ of Aronia berries. These researchers focused only on selected essential elements. Their results for calcium iron, magnesium and zinc (Table 5) are much higher than those obtained in the present study. This was, on the one hand, due to a higher amount of plant matter per water and, on the other hand, due to other extraction conditions. Savikin and colleagues also studied infusions from Aronia berries, but only for the phenolic and anthocyanin content [6].

For all elements detected in the infusions the extraction yields were calculated according to the formula below and the values are listed in Table 5. They range from 4 to $44 \%$. Thus, Aronia teas contain not only phenolic compounds of nutritional importance, but also essential elements.

$$
\text { extraction yield }_{x}[\%]=\frac{c_{x, \text { infusion }}[\mu \mathrm{g} / \mathrm{L}] \times V_{\text {infusion }}[\mathrm{L}]}{m_{\text {berry }}[\mathrm{g}] \times w_{x, \text { berry }}[\mu \mathrm{g} / \mathrm{g}]}
$$

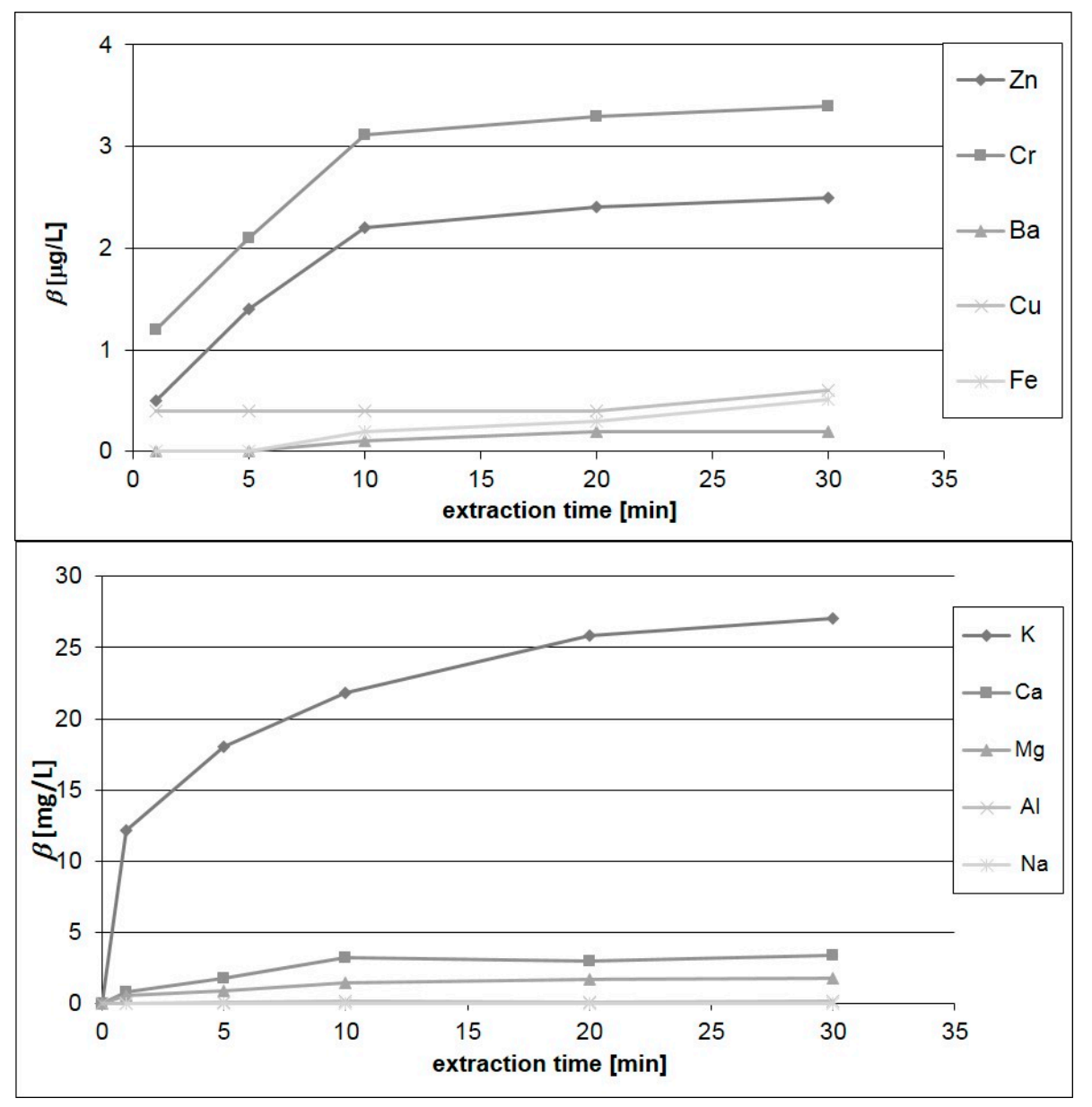

Figure 1. Concentrations of macro- and microelements in infusions after different extraction times. 


\section{Conclusions}

Aronia berries as well as infusions derived from them are a good dietary source of essential metals in addition to the organic compound contained.The nutrients $\mathrm{Ca}, \mathrm{K}$ and $\mathrm{Mg}$ are present in the fruits (dried matter) at $\mathrm{g} / \mathrm{kg}$ level, whereas the other elements are in the $\mu \mathrm{g} / \mathrm{kg}$ to $\mathrm{mg} / \mathrm{kg}$ range. As, Ba, and Se were below the limit of detection. Infusions of the chokeberries investigated are a good dietary source of essential metals especially regarding $\mathrm{Ca}, \mathrm{Cu}, \mathrm{Fe}, \mathrm{K}, \mathrm{Mg}, \mathrm{Mn}, \mathrm{Na}, \mathrm{Ni}$, and $\mathrm{Zn}$. In addition to the known beneficial impact from its organic compounds, the mineral composition justifies its usage as nutritional supplement. The toxic elements present do not pose any health risk when berries or infusions are consumed.

Author Contributions: Michaela Zeiner and Iva Juranovic Cindric conceived and designed the experiments; Darija Mihajlov-Konanov performed the digestions and preparation of infusions; Darija Mihajlov-Konanov, Iva Juranović Cindrić and Michaela Zeiner carried out the measurements; Gerhard Stingeder contributed reagents and analysis tools; Michaela Zeiner and Iva Juranović Cindrić analyzed the data and wrote the paper; Michaela Zeiner revised the paper.

Conflicts of Interest: The authors declare no conflict of interest.

\section{References}

1. Kokotkiewicz, A.; Jaremicz, Z.; Luczkiewicz, M. Aronia plants: A review of traditional use, biological activities, and perspectives for modern medicine. J. Med. Food 2010, 13, 255-269. [CrossRef] [PubMed]

2. WertvollJournal for Members of "Mein Clubhaus" Ausgabe, 2015 p 12. Available online: http:/ /www.meinclubhaus.com/at/aktuell/wertvoll (accessed on 5 May 2016).

3. Kulling, S.E.; Rawel, H.M. Chokeberry (Aronia melanocarpa)—A review on the characteristic components and potential health effects. Planta Med. 2008, 74, 1625-1634. [CrossRef] [PubMed]

4. Lee, J.E.; Kim, G.-S.; Park, S.; Kim, Y.-H.; Kim, M.-B.; Lee, W.S.; Jeong, S.W.; Lee, S.J.; Jin, J.S.; Shin, S.C. Determination of chokeberry (Aronia melanocarpa) polyphenol components using liquid chromatography-tandem mass spectrometry: Overall contribution to antioxidant activity. Food Chem. 2014, 146, 1-5. [CrossRef] [PubMed]

5. Park, S.; Kim, J.I.; Lee, I.; Lee, S.; Hwang, M.-W.; Bae, J.-Y.; Heo, J.; Kim, D.; Han, S.-Z.; Park, M.-S. Aronia melanocarpa and its components demonstrate antiviral activity against influenza viruses. Biochem. Biophys. Res. Commun. 2013, 440, 14-19. [CrossRef] [PubMed]

6. Šavikin, K.; Zdunić, G.; Janković, T.; Gođevac, D.; Stanojković, T.; Pljevlakušić, D. Berry fruit teas: Phenolic composition and cytotoxic activity. Food Res. Int. 2014, 62, 677-683. [CrossRef]

7. Lala, G.; Malik, M.; Zhao, C.; He, J.; Kwon, Y.; Giusti, M.M.; Magnuson, B.A. Anthocyaninrich extracts inhibit multiple biomarkers of colon cancer in rats. Nutr. Cancer 2006, 54, 84-93. [CrossRef] [PubMed]

8. Bermúdez-Soto, M.J.; Larrosa, M.; García-Cantalejo, J.; Espín, J.C.; Tomás-Barberan, F.A.; García-Conesa, M.T. Up-regulation of tumor suppressor carcinoembryonic antigen-related cell adhesion molecule 1 in human colon cancer Caco-2 cells following repetitive exposure to dietary levels of a polyphenol-rich chokeberry juice. J. Nutr. Biochem. 2007, 18, 259-271. [CrossRef] [PubMed]

9. Veberic, R.; Slatnar, A.; Bizjak, J.; Stampar, F.; Mikulic-Petkovsek, M. Anthocyanin composition of different wild and cultivated berry species. Food Sci. Technol. 2015, 60, 509-517. [CrossRef]

10. Nakajima, J.; Tanaka, I.; Seo, S.; Yamazaki, M.; Saito, K. LC/PDA/ESI-MS profiling and radical scavenging activity of anthocyanins in various berries. J. Biomed. Biotechnol. 2004, 5, 241-247. [CrossRef] [PubMed]

11. Šnebergrová, J.; Čižková, H.; Neradová, E.; Kapci, B.; Rajchl, A.; Voldřich, M. Variability of characteristic components of Aronia. Czech J. Food Sci. 2014, 32, 25-30.

12. Nile, S.H.; Park, S.W. Edible berries: Bioactive components and their effect on human health. Nutrition 2014, 30, 134-144. [CrossRef] [PubMed]

13. Chandler, F.B. Composition and uses of blueberries. Maine Agric. Exp. Station Bull. 1944, 428, 1-39.

14. Konieczynski, P.; Arceusz, A.; Wesolowski, M. Relationships between flavonoids and selected elements in infusions of medicinal herbs. Open Chem. 2015, 13, 68-74. [CrossRef]

15. Skupien, K.; Oszmianski, J. The effect of mineral fertilization on nutritive value and biological activity of chokeberry fruit. Agric. Food Sci. 2007, 16, 46-55. [CrossRef] 
16. Borycka, B.; Stachowiak, J. Relations between cadmium and magnesium and aronia fractional dietary fibre. Food Chem. 2008, 107, 44-48. [CrossRef]

17. Nawirska, A. Binding of heavy metals to pomace fibers. Food Chem. 2005, 90, 395-400. [CrossRef]

18. Soylak, M.; Tuzen, M.; Souza, A.S.; das Graças Andrade, K.M.; Ferreira, S.L. Optimization of microwave assisted digestion procedure for the determination of zinc, copper and nickel in tea samples employing flame atomic absorption spectrometry. J. Hazard. Mater. 2007, 149, 264-268. [CrossRef] [PubMed]

19. Boumans, P.W.J.M. Basic concepts and characteristics of ICP-AES. In Inductively Coupled Plasma Emission Spectroscopy Part I Methodology, Instrumentation, and Performance; Boumans, P.W.J.M., Ed.; Wiley: New York, NY, USA, 1987; pp. 100-257.

20. Tanaka, T.; Tanaka, A. Chemical components and characteristics of black chokeberry. J. Jpn. Soc. Food Sci. Technol. 2001, 48, 606-610. [CrossRef]

21. Ognik, K.; Rusinek, E.; Sembratowicz, I.; Truchlinski, J. Contents of heavy metal, nitrate (V), and nitrate (III) in fruits of elderberry and black chokeberry depending on harvest site and vegetation period. Rocz. Państw. Zakl. Hig. 2006, 57, 235-241. [PubMed]

22. Juranović Cindrić, I.; Zeiner, M.; Mihajlov-Konanov, D.; Stingeder, G. Metal characterization of white hawthorn organs and infusions. J. Agric. Food Chem. 2015, 63, 1798-1802. [CrossRef] [PubMed]

23. Pliszka, B.; Huszcza-Ciołkowska, G.; Wierzbicka, E. Effects of extraction conditions on the content of anthocyanins and bioelements in berry fruit extracts. Commun. Soil Sci. Plant Anal. 2008, 39, 753-762. [CrossRef]

24. Zeiner, M.; Juranović Cindrić, I.; Majić, B.; Stingeder, G. Study of the accumulation of Toxic and Essential Ultra-Trace Elements in Fruits of Sorbus domestica L. Int. J. Environ. Res. Public Health 2017, 14, 341. [CrossRef] [PubMed]

25. Food and Nutrition Board, Institute of Medicine. Dietary Reference Intakes, Standing Committee on the Scientific Evaluation of Dietary Reference Intakes; National Academies Press: Washington, DC, USA, 1997.

26. World Health Organization (WHO). Evaluation of Certain Food Additives and Contaminants (41st Report of the Joint FAO/WHO Expert Committee on Food Additives); WHO Technical Report Series No 837; World Health Organization: Geneva, Switzerland, 1993.

27. WHO. Chromium in Drinking-Water, Guidelines for Drinking Water Quality, 2nd ed.; World Health Organization: Geneva, Switzerland, 1996; Volume 2. 